\title{
Analisis Kepuasan Pasien dan Pelaksana Terhadap Sistem Informasi Manajemen Puskesmas Elektronik (Simpustronik) di Kabupaten Blitar Menggunakan Regresi Logistik Biner
}

\author{
Rahmad Adi Subektianto ${ }^{1}$, Madu Ratna ${ }^{2}$, Ismaini Zain ${ }^{3}$ \\ Departemen Statistika, Fakultas Matematika, Komputasi, dan Sains Data \\ Institut Teknologi Sepuluh Nopember (ITS) \\ Jl. Arief Rahman Hakim, Surabaya 60111 Indonesia \\ e-mail:madu_r@statistika.its.ac.id ${ }^{2}$,ismaini_z@statistika.its.ac.id ${ }^{3}$
}

\begin{abstract}
Abstrak - Dinas Kesehatan Kabupaten Blitar berusaha meningkatkan kualitas kesehatan. Salah satunya dengan adanya Sistem Informasi Manajemen Puskesmas Elektronik (Simpustronik). Simpustronik mempermudah perekapan data pasien dan integrasi rekam medik pasien dengan pelayanan kesehatan lainnya. Sistem berjalan dengan baik ketika pengguna merasa puas terhadap sistem tersebut, oleh karena itu pada penelitian ini dilakukan analisis kepuasan pasien dan pelaksana terhadap Simpustronik. Mulai dari kesenjangan antara harapan dan kenyataan yang terjadi, posisi kuadran dari setiap dimensi yang perlu diperbaiki, indeks kepuasan, dan model regresi logistik biner untuk mengetahui faktor yang mempengaruhi kepuasan pasien dan pelaksana terhadap Simpustronik. Data analisis diperoleh dengan survey dengan jumlah sampel 120 pelaksana dan 140 pasien menggunakan simple random sampling. Hasil akhir diperoleh 15 indikator dengan 5 dimensi pembentuk kepuasan pasien dan 13 indikator dengan 6 dimensi pembentuk kepuasan pelaksana dapat disimpulkan valid dan reliabel. Pasien dan Pelaksana ternyata masih merasakan Gap atau kesenjangan antara harapan dan kenyataan terhadap Simpustronik. Namun jika secara indeks kepuasan persentase kepuasan pasien sebesar 0,7336 dan kepuasan pelaksana 0,659 . Jika dilihat dari Importance Performance Analysis (IPA) bagi pasien, pengelola sistem perlu melakukan perbaikan faktor responsif dari Simpustronik, sedangkan untuk pelaksana tidak perlu dilakukan perbaikan. Hasil regresi logistik biner untuk pasien dari 11 variabel karakteristik diperoleh 5 variabel karakteristik ber-pengaruh signifikan dengan ketepatan klasifikasi model sebesar $67,1 \%$ dan untuk pelaksana dari 12 variabel karakteristik diperoleh 6 variabel karakteristik ber-pengaruh signifikan dengan sebesar $61,7 \%$.
\end{abstract}

Kata Kunci - Analisis Gap, Importance Performance Analysis, Indeks Kepuasan, Simpustronik, Regresi Logistik Biner.

\section{PENDAHULUAN}

$\mathrm{D}$ inas Kesehatan Kabupaten Blitar mulai menggunakan salah satu terobosan baru untuk mempermudah sistem pelaporan kesehatan dan memperbaiki kualitas pelayanan kesehatan yaitu Sistem Informasi Manajemen Puskesmas Elektronik (Simpustronik) pada tahun 2010. Penggunaan Simpustronik diharapkan mampu membantu mempercepat proses pelayanan kesehatan khususnya di Puskesmas. Penggunaan Simpustronik adalah masih terdapat ketidakvalidan data mengenai orang sakit, jenis penyakit, ibu hamil, rekam medik pasien dan pelayanan kesehatan lain di setiap puskesmas, serta untuk memperbaiki pengumpulan data di Puskesmas guna memberikan laporan lengkap dan terkini ke Dinas Kesehatan Kabupaten Blitar. Berdasarkan informasi sub bidang penyusunan program Dinas Kesehatan Kabupaten Blitar pada tahun 2010 hingga 2017, diketahui masih terdapat kesenjangan antara harapan dan kenyataan dalam penggunaan Simpustronik seperti kesulitan dalam penggunaan, pemahaman terhadap sistem yang kurang, hingga pasien yang merasa lama mengantri ketika menggunakan Simpustronik.

Hal ini membuat Dinas Kesehatan perlu melakukan evaluasi terhadap penggunaan Simpustronik disaat sebelum dan sesudah adanya sistem tersebut. Penggunaan analisis gap untuk mengetahui seberapa besar kesenjangan antara kinerja dan harapan terhadap Simpustronik dimana uji ini merupakan pengujian dua sampel berhubungan [1]. Importance performance analysis digunakan untuk mengidentifikasi faktor-faktor kinerja penting apa yang harus ditunjukkan oleh suatu organisasi [2]. Indeks kepuasan untuk mengetahui tingkat kepuasan pengguna Simpustronik secara menyeluruh baik dari sisi pasien dan pelaksana (operator) dengan melihat tingkat kepentingan dari atribut-atribut sistem yang digunakan [3]. Penggunaan regresi logistik biner karena pengukuran kepuasan tidak dapat diukur secara langsung, melainkan melalui beberapa dimensi, kemudian di-break down menjadi beberapa indikator. Masing-masing indikator akan diberi skor ukuran tinggi dan rendah terhadap harapan serta kenyataan yang terjadi selama ini, pemberian skor pada indikator akan digunakan sebagai variabel respon untuk mengukur kepuasan pengguna terhadap Simpustronik dengan dua kategori, yaitu puas dengan kategori 1 dan tidak puas dengan kategori 0 , karena variabel respon yang bersifat ketegorik maka penggunaan regresi logistik biner tepat dilakukan [4].

Penggunaan beberapa metode tersebut diharapkan mampu memberikan solusi maksimal dengan menerapkan metode yang mudah dilakukan Dinas Kesehatan Kabupaten Blitar untuk 
melakukan analisis kepuasan terhadap Simpustronik berdasarkan hasil jawaban pasien dan pelaksana sebagai bahan evaluasi guna peningkatan berkelanjutan. Rumusan masalah pada penelitian ini, ingin mengetahui apakah terdapat kesenjangan antara harapan dan kenyataan pasien dan pelaksana terhadap Simpustronik, posisi kuadran dari faktor atau dimensi kepuasan pasien dan pelaksana, indeks kepuasan, dan model logit serta ketepatan klasifikasi kepuasan pasien dan pelaksana terhadap Simpustronik. Tujuan pada penelitian ini tentunya menjawab rumusan masalah yang ada.

\section{TINJAUAN PUSTAKA}

\section{A. Faktor Kepuasan}

Kepuasan terhadap Simpustronik sangat diperlukan sebagai salah satu bahan evaluasi dari pasien dan pelaksana, dimana kepuasan merupakan tingkat perasaan seseorang setelah membandingkan kinerja atau hasil yang dirasakannya dengan harapannya, dimana seseorang tersebut dapat merasakan senang atau kecewa [2]. Dimensi yang digunakan untuk mengukur kepuasan pasien terhadap Simpustronik dengan penyesuaian, yaitu: Tangibles (penampilan fisik), Reliability (kehandalan), Responsiveness (ketanggapan), Assurance (jaminan), dan Empathy (empati) [5].

Dimensi pengukuran kepuasan terhadap sistem informasi yang dapat digunakan tolok ukur oleh pelaksana, dimana kepuasan terhadap sistem informasi yang berbasis digital dapat diukur menggunakan 6 (enam) dimensi dengan penyesuaian diantaranya: Kualitas Sistem, Kualitas Informasi, Kualitas Pelayanan, Penggunaan, Kepuasan pengguna, dan Keuntungan [6]. Sistem informasi manajemen puskesmas elektronik (Simpustronik) merupakan salah satu pembaharuan sistem manajemen data untuk keperluan kegiatan di puskesmas yang terintegrasi dan didesain multi user yang disiapkan untuk menangani keseluruhan proses manajemen puskesmas.

\section{B. Pendekatan Metode Statistika}

Statistika Deskriptif merupakan metode-metode yang berkaitan dengan pengumpulan dan penyajian suatu gugus data sehingga memberikan informasi yang berguna [7]. Dalam penelitian ini statistika deskriptif digunakan untuk mengetahui pola dan karakteristik baik dari pengguna Simpustronik dan hasil dari analisis kesenjangan, IPA, dan analisis kepuasan, sehingga mampu memberikan gambaran terhadap puskesmas, dinas kesehatan dan pemerintah setempat bagaimana kondisi yang sebenarnya.

\section{Analisis Gap}

Analisis Gap merupakan uji kesenjangan harapan dan kenyataan atau uji wilcoxon digunakan untuk mengetahui seberapa besar kesenjangan antara kinerja dan harapan terhadap Simpustronik dimana uji ini merupakan pengujian dua sampel berhubungan pada prinsipnya ingin menguji apakah dua sampel yang berpasangan satu dengan yang lain berasal dari populasi yang sama atau berbeda [1]. Hipotesis sebagai berikut.

$\mathrm{H}_{0}: \mathrm{d}=0$, artinya tidak ada kesenjangan antara kinerja dengan harapan

$\mathrm{H}_{1}: \mathrm{d} \neq 0$, artinya ada kesenjangan antara kinerja dengan harapan
Statistik uji :

$$
Z=\frac{\min \left(T_{(+)}, T_{(-)}\right)-(n(n+1) / 4)}{\sqrt{\frac{n(n+1)(2 n+1)}{24}-\frac{\sum t^{3}-\sum t}{48}}}
$$

Dengan membandingkan angka $Z_{\text {hitung }}$ dan $Z_{(1-\alpha / 2)}$ :

Jika $Z_{\text {hitung }}>\mathrm{Z}_{(1-a / 2)}$, maka $\mathrm{H}_{0}$ diterima, Jika $Z_{\text {hitung }}<\mathrm{Z}_{(1-\mathrm{o} / 2)}$, maka $\mathrm{H}_{0}$ ditolak. Jika melihat angka probabilitas, jika Probabilitas > 0,05 maka $\mathrm{H}_{0}$ diterima sedangkan jika probabilitas $<0,05$ maka $\mathrm{H}_{0}$ ditolak.

\section{Importance Performance Analysis (IPA)}

Importance Performance Analysis adalah suatu teknik analisis yang digunakan untuk mengidentifikasi faktor-faktor kinerja penting apa yang harus ditunjukkan oleh suatu organisasi dalam memenuhi kepuasan para pengguna sistem pada kasus ini ialah pasien dan pelaksana [2].

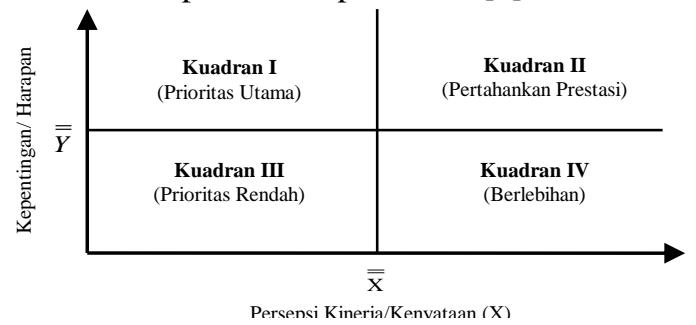

Gambar 1. Diagram Kartesius Analisis IPA

Terdapat empat kuadran dalam Importance Performance Analysis (IPA) dengan penjelasan sebagai berikut:

i. Prioritas Utama

Pada kuadaran ini terdapat faktor-faktor yang dianggap penting dan perlu segera diperbaiki utnuk menjaga kepuasan Pasien dan Pelaksana terhadap Simpustronik.

ii. Pertahankan Prestasi

Pada kuadaran ini terdapat faktor-faktor yang dianggap penting dan memberikan hasil maksimal, sehingga pengelola Simpustronik wajib untuk mempertahankan prestasi kinerja tersebut.

iii. Prioritas Rendah

Pada kuadaran ini terdapat faktor-faktor yang dianggap mempunyai tingkat persepsi yang rendah dan tidak terlalu penting sehingga pengelola Simpustronik tidak perlu memberikan perhatian lebih pada faktor-faktor tersebut.

iv. Berlebihan

Pada kuadaran ini terdapat faktor yang dianggap tidak terlalu penting oleh pengguna sehingga pengelola Simpustronik lebih baik mengalokasikan sumber daya yang terkait pada faktor tersebut kepada faktor lain.

\section{Indeks Kepuasan Pengguna}

Indeks Kepuasaan Pengguna ini digunakan untuk mengetahui tingkat kepuasan pengguna Simpustronik secara menyeluruh baik dari sisi pasien dan pelaksana (operator) dengan melihat tingkat kepentingan dari atribut-atribut sistem yang digunakan [3]. Tabel 1 menunjukkan nilai indeks kepuasan pengguna (pasien dan pelaksana) terhadap Simpustronik. 
Tabel 1 Nilai Indeks Kepuasan Pengguna

\begin{tabular}{ccc}
\hline No. & $\begin{array}{c}\text { Nilai Indeks } \\
\text { Kepuasan Pengguna }\end{array}$ & Kriteria \\
\hline 1. & $\mathrm{X}>0,80$ & Sangat Puas \\
2. & $0,65<\mathrm{X} \leq 0,80$ & Puas \\
3. & $0,50<\mathrm{X} \leq 0,65$ & Cukup Puas \\
4. & $0,34<\mathrm{X} \leq 0,50$ & Kurang Puas \\
5. & $0,00<\mathrm{X} \leq 0,34$ & Tidak Puas \\
\hline
\end{tabular}

Pengukur nilai harapan dan kenyataan pada penelitian ini skala yang dipakai mulai dari 1 yang sangat rendah hingga 7 yang sangat tinggi, atau jika di bahasakan menjadi Sangat Tidak Sesuai, Tidak Sesuai, Kurang Sesuai, Cukup Sesuai, Sesuai, Sangat Sesuai dan Sangat Sesuai Sekali.

\section{Confirmatory Factor Analysis (CFA)}

CFA merupakan metode statistik yang menggambarkan hubungan antara variabel laten dengan indikator dan digunakan untuk menguji model pengukurannya [8]. Tujuan analisis faktor konfirmatori (CFA) untuk mengkonfirmasi dan menguji pertanyaan dalam kuisioner apakah sudah representatif (valid) dan akurat atau konsisten (reliabel). Variabel dikatakan valid apabila menghasilkan loading factor $>0,5$ dan $p$-value < 0,05. Ukuran ini dapat diterima kehandalannya apabila koefisien construct reliability $(\mathrm{CR})>$ 0,70 dan menunjukkan reliabilitas tinggi, sedangkan bila 0,60 $\leq \mathrm{CR} \leq 0,70$ juga dapat diterima dan menunjukkan bahwa indikator pada konstruk model telah baik [9]. Pada penelitian ini menggunakan CFA order kedua, dari hasil CFA akan diperoleh nilai skor faktor, kemudian menjadi kriteria penentuan puas dan tidak puas, jika skor faktor responden kurang dari nilai median maka dikategorikan tidak puas, jika lebih dari sama dengan nilai median maka dikategorikan puas. (Y) untuk kepuasan pasien, dan (Y*) untuk kepuasan pelaksana

\section{Regresi Logistik Biner}

Pengukuran kepuasan tidak dapat diukur secara langsung, melainkan melalui beberapa dimensi, kemudian di-break down menjadi beberapa indikator. Masing-masing indikator akan diberi skor ukuran tinggi dan rendah terhadap harapan serta kenyataan yang terjadi selama ini, pemberian skor pada indikator akan digunakan sebagai variabel respon untuk mengukur kepuasan pengguna terhadap Simpustronik dengan dua kategori, yaitu puas (1) dan tidak puas (0), karena variabel respon yang bersifat ketegorik maka penggunaan regresi logistik biner tepat dilakukan [4].

a. Penduga Parameter

Penduga parameter dalam regresi logistik dilakukan dengan metode Maximum Likelihood (MLE). Metode MLE memberikan nilai estimasi $\beta$ dengan memaksimumkan fungsi likelihood [4]. Fungsi likelihood sebagai berikut

$$
\begin{aligned}
L(\boldsymbol{\beta}) & =\ln l(\boldsymbol{\beta}) \\
& =\sum_{i=1}^{n}\left\{y_{i} \ln \left[\pi\left(x_{i}\right)\right]+\left(1-y_{i}\right) \ln \left[1-\pi\left(x_{i}\right)\right]\right\} \\
& =\sum_{j=0}^{p}\left(\sum_{i=1}^{n} y_{i} x_{i j}\right) \beta_{j}-\sum_{i=1}^{n} \ln \left(1+e^{\sum_{j=0}^{p} \beta_{j} x_{i j}}\right)
\end{aligned}
$$

Nilai $\boldsymbol{\beta}$ maksimum didapatkan melalui turunan $\mathrm{L}(\boldsymbol{\beta})$ terhadap $\boldsymbol{\beta}$ dan hasilnya adalah sama dengan nol. Teori tersebut menyatakan bahwa estimasi varians kovarians didapatkan melalui turunan kedua $\mathrm{L}(\boldsymbol{\beta})$.

$$
\hat{C} \operatorname{ov}(\hat{\boldsymbol{\beta}})=\left(\mathbf{X}^{T} \operatorname{diag}\left[\hat{\pi}_{i}\left(x_{i}\right)\left(1-\hat{\pi}_{i}\left(x_{i}\right)\right)\right] \mathbf{X}\right)^{-1}
$$

b. Penduga Parameter

Pengujian terhadap parameter-parameter estimasi model dilakukan untuk mengetahui peran seluruh variabel prediktor baik secara simultan (bersama-sama) maupun secara parsial.

Hipotesis :

$\mathrm{H}_{0}: \beta_{1}=\beta_{2}=\ldots=\beta_{\mathrm{p}}=0$ (tidak ada pengaruh signifkan variabel prediktor terhadap variabel respons)

$\mathrm{H}_{1}$ : minimal ada satu $\beta_{j} \neq 0$ dimana $\mathrm{j}=1,2, \ldots \mathrm{p}$

Statistik uji pada persamaan 4.

$$
G=-2 \ln \frac{\left(\frac{n_{1}}{n}\right)^{n_{1}}\left(\frac{n_{0}}{n}\right)^{n_{0}}}{\sum_{i=1}^{n} \hat{\pi}_{i}^{y_{i}}\left(1-\hat{\pi}_{i}\right)^{\left(1-y_{i}\right)}}
$$

Dimana : $n_{1}=\sum_{i=1}^{n} y_{i} \quad n_{0}=\sum_{i=1}^{n}\left(1-y_{i}\right) \quad n=n_{1}+n_{0}$

Pada taraf signifikansi $\alpha$, hipotesisi nol $\left(H_{0}\right)$ ditolak apabila $G>\chi_{d . b, \alpha}^{2}$ atau $p$-value $<\alpha$. Sedangkan pengujian parameter $\beta$ secara parsial dilakukan dengan membandingkan model terbaik yang dihasilkan oleh uji simultan terhadap model tanpa variabel bebas di dalam model terbaik.

$$
W=\left[\frac{\hat{\beta}}{S E\left(\hat{\beta}_{j}\right)}\right]^{2}
$$

Dengan $S E\left(\hat{\beta}_{j}\right)$ merupakan standar error koefisien $\hat{\beta}_{j}$ dari $\sqrt{\operatorname{Var}\left(\hat{\beta}_{j}\right)}$ dimana $\hat{\beta}_{j}$ merupakan nilai koefisien dugaan variabel prediktor. Uji Wald mengikuti sebaran normal baku $Z, \mathrm{H}_{0}$ akan ditolak jika $W>Z_{\alpha / 2}$ atau $p$-value $<\alpha$. Penggunaan Odds ratio dilakukan untuk menunjukkan besarnya perubahan nilai variabel respon untuk setiap perubahan satu unit variabel prediktor untuk variabel variabel prediktor yang signifikan [4].

c. Uji Kesesuaian Model

Pengujian kesesuaian model dilakukan dengan menggunakan Hosmer-Lemeshow Goodness of Fit.

Hipotesis :

$\mathrm{H}_{0}$ : Model sesuai

$\mathrm{H}_{1}$ : Model tidak sesuai

Statistik uji :

$$
\hat{C}=\sum_{k=1}^{K} \frac{\left(o_{k}-n_{k} \bar{\pi}_{k}\right)^{2}}{n_{k}^{\prime} \bar{\pi}_{k}\left(1-\bar{\pi}_{k}\right)}
$$

Statistik uji Hosmer-Lemeshow mengikuti distribusi Chisquare dengan derajat bebas sebesar $k-2$ sehingga diperoleh keputusan tolak $H_{0}$ jika nilai $\hat{C}$ lebih dari $\chi_{(k-2)}^{2}$ atau $P$ Value kurang dari $\alpha$ [4].

d. Ketepatan Klasifikasi

Evaluasi ketepatan klasifikasi merupakan suatu evaluasi untuk melihat peluang kesalahan klasifikasi yang dilakukan oleh suatu fungsi klasifikasi. Perhitungan ketepatan klasifikasi untuk keadaan seimbang (balanced) dilakukan dengan menggunakan nilai Apparent Error Rate (APER).

$$
\text { APER }=\frac{n_{12}+n_{21}}{n_{11}+n_{12}+n_{21}+n_{22}} \times 100 \%
$$


dimana :

$\mathrm{n}_{11}$ : jumlah dari subjek dari $\mathrm{y}_{1}$ salah diklasifikasikan sebagai

$\mathrm{y}_{1}$

$\mathrm{n}_{12}$ : jumlah dari subjek dari $\mathrm{y}_{1}$ salah diklasifikasikan sebagai

$\mathrm{y}_{2}$

$\mathrm{n}_{21}$ : jumlah dari subjek dari $\mathrm{y}_{2}$ salah diklasifikasikan sebagai

$\mathrm{y}_{1}$

$\mathrm{n}_{22}$ : jumlah dari subjek dari $\mathrm{y}_{2}$ tepat diklasifikasikan sebagai $\mathrm{y}_{2}$

\section{Sumber Data}

\section{METODOLOGI PENELITIAN}

Data yang digunakan dalam penelitian ini merupakan data primer berdasarkan survei langsung ke 120 pelaksana dan 140 pasien yang tersebar di seluruh kecamatan Kabupaten Blitar. Survei dilakukan selama minggu awal bulan Mei 2018. Penentuan ukuran sampel dan alokasi sampel untuk menaksir proporsi populasi menggunakan pendekatan dari setiap strata [10]. Pasien dan pelaksana dibagi dalam 24 strata, dalam penelitian ini puskesmas sebagai strata. Kemudian melakukan sampling terhadap pasien dan pelaksana pada setiap puskemas dengan menggunakan simple random sampling. Sehingga diperoleh jumlah sampel yang sesuai dengan jumlah populasi pasien dari masing-masing puskesmas (strata).

\section{Variabel Penelitian}

Variabel penelitian yang digunakan dalam penelitian ini karakteristik pasien terdiri dari 11 karakteristik yaitu jenis kelamin, pekerjaan, usia, pendidikan terakhir, jenis pelayanan yang dipilih, pasien mengetahui Simpus, intensitas data ke puskesmas pada bulan April, jarak tempat tinggal, info lengkap bagi pasien, durasi pelayanan, dan tipe pembayaran. Variabel karakteristik pelaksana terdiri dari 12 karakteristik yaitu jenis kelamin, usia, pendidikan terakhir, jabatan, masa kerja, jumlah operator Simpus, intensitas menggunakan Simpus, jumlah teknisi IT, intensitas ikut sosialisasi Simpus, jarak tempat tinggal, info lengkap bagi pelaksana, dan durasi pelayanan.

\section{Langkah Analisis}

a.Langkah analisis yang dilakukan pada penelitian ini sebelum menjawab tujuan 1, 2, 3, dan 4 adalah sebagai berikut.

a) Melakukan survey pendahuluan (pra survei).

b) Melakukan uji validitas dan pengukuran reliabilitas berdasarkan hasil pra survei

c) Melakukan survey lapangan (pasca survei).

d) Melakukan prepocessing data.

e) Melakukan uji validitas dan reliabilitas menggunakan metode analisis faktor konfirmatori untuk memperoleh hasil indikator maksimal sehingga bisa dilanjutkan analisis selanjutnya.

f) Mengeksplorasi data karakteristik dari pengguna Simpustronik.

b. Menjawab tujuan penelitian pertama adalah sebagai berikut.

a) Menentukan peringkat positif dan peringkat negatif dari selisih nilai harapan dan kenyataan berdasarkan indikator maksimal, kemudian dijumlahkan

b) Melakukan analisis kesenjangan (Gap) dengan menggunakan uji Wilcoxon.

c. Menjawab tujuan penelitian kedua adalah sebagai berikut. a) Menghitung nilai rata-rata kenyataan dan harapan dari setiap dimensi pengukur kepuasan berdasarkan indikator maksimal.

b) Menentukan posisi kuadran berdasarkan nilai rata-rata harapan dan kenyataan setiap dimensi, dimana nilai standar sumbu $\mathrm{X}$ (kenyataan) dan $\mathrm{Y}$ (harapan) menggunakan nilai rata-rata keseluruhan.

d. Menjawab tujuan penelitian ketiga adalah sebagai berikut.

a) Menentukan rata-rata skor pentingnya nilai

b) Menghitung nilai faktor tertimbang atau persentase ratarata skor penting nilai per dimensi.

c) Menghitung nilai skor tertimbang hasil perkalian faktor tertimbang dengan rata-rata tingkat kepuasan.

d) Menghitung nilai indeks kepuasan.

e. Menjawab tujuan penelitian keempat adalah sebagai berikut.

a) Penentuan model awal regresi logistik biner untuk pasien dan pelaksana.

b) Melakukan pengujian serentak dan uji parsial terhadap model awal.

c) Melakukan pengujian kesesuaian model regresi pasien dan pelaksana.

d) Interpretasi nilai Odds ratio dari variabel yang signifikan terhadap model.

e) Menghitung ketepatan klasifikasi model.

f. Menarik kesimpulan dan saran.

\section{ANALISIS DAN PEMBAHASAN}

\section{A. Hasil Uji Validitas dan Uji Reliabilitas}

Berdasarkan hasil uji validitas diketahui hasil indikator yang memenuhi kriteria nilai Critical Ratio (CR) > 1,96 dengan Probability (P) $<0,05$ dimana tanda $* * *$ adalah signifikan $<0,001$ dan nilai estimasi standardized atau loading factor lebih dari 0,5. Untuk pasien yaitu Dimensi Responsiveness dengan Res1, Res2, dan Res3. Dimensi Reliability dengan Rel2, Rel3, dan Rel5. Dimensi Tangible dengan Tan1, Tan2, dan Tan3. Dimensi Assurance dengan Ass1, Ass2, Ass3, dan Ass4. Serta, Dimensi Empathy dengan Emp1 dan Emp2, dengan total seluruhnya 15 indikator. Sedangkan hasil uji reliabilitas kelima dimensi dapat dihandalkan, karena nilai dari construct reliability (CR) yang dihasilkan $>0,70$.

Sedangkan uji validitas dan reliabilitas untuk pelaksana diperoleh hasil indikator yang memenuhi kriteria diperoleh Dimensi Pengguna dengan P3 dan P4. Kepuasan Pengguna dengan KP2, sedangkan Karena syarat suatu dimensi memerlukan minimal 2 variabel maka KP3 (meningkatkan efektivitas dan efisiensi kerja) tetap diikutkan untuk membentuk dimensi kepuasan pengguna.

Kualitas Sistem dengan KS1, dan KS2. Kualitas Informasi dengan KI2 dan KI5. Keuntungan dengan KU2 dan KU3. Serta, Kualitas Pelayanan dengan KL1, KL2, dan KL5. Total indikator menjadi 13 indikator. Sedangkan untuk uji reliabilitasnya bahwa semua dimensi dapat dihandalkan kecuali pada dimensi Kepuasan Pengguna hal ini juga imbas dari salah satu variabel pembentuk dimensi yang tidak valid, namun dimensi kepuasan pengguna tetap digunakan karena mengikuti tinjauan pustaka. 


\section{B. Deskriptif Variabel Penelitian}

Gambar 2 berisikan deskriptif variabel penelitian dari pasien puskesmas yang diduga Dinas Kesehatan Kabupaten Blitar mempunyai pengaruh terhadap kepuasan pelaksana terhadap Simpustronik sebagai berikut.

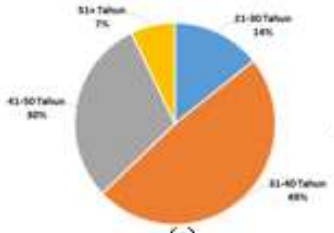

(a)

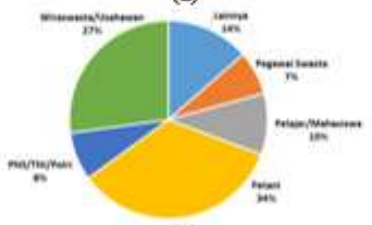

(c)

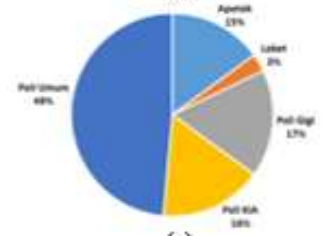

(e)

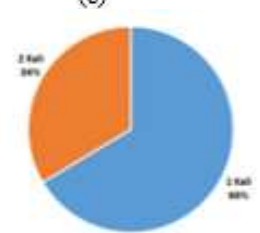

(g)

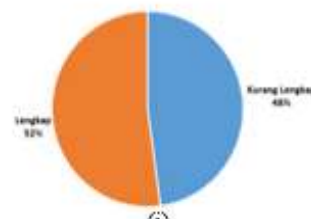

(i)

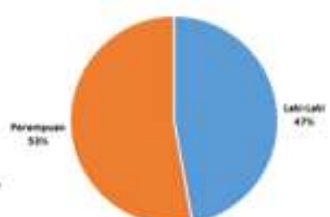

(b)

(d)

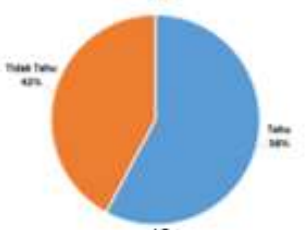

(f)

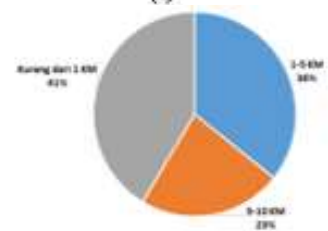

(h)

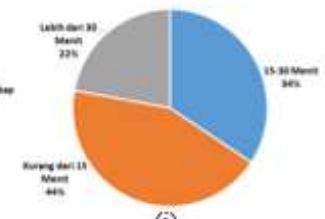

(j)
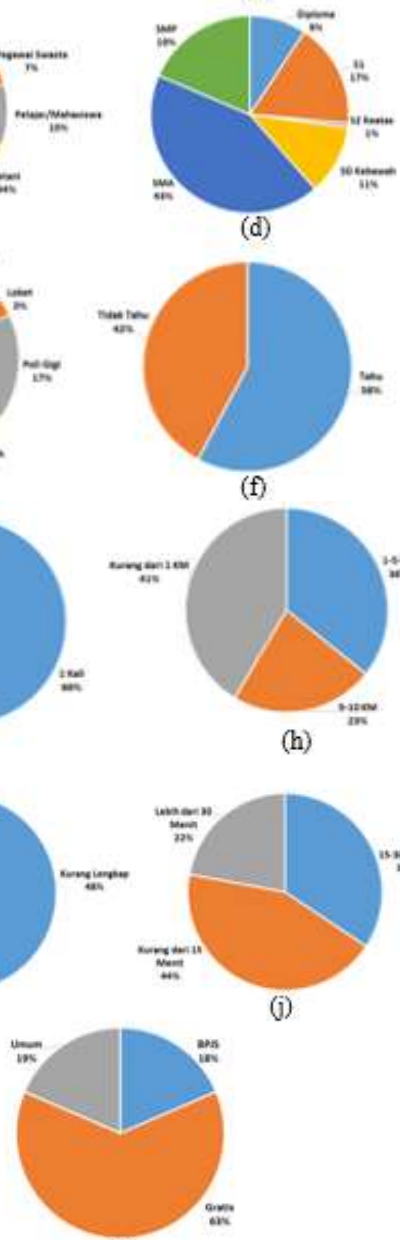

(k)

Gambar 2. Karakteristik Pasien

Berdasarkan karakteristik pasien jika dilihat dari demografi penduduk Gambar (a) menunjukkan bahwa rata-rata umur responden pada survei kepuasan pasien paling banyak pada umur 31-40 tahun yaitu sebesar 49\% untuk pasien atau sebesar 68 . Kemudian rata-rata umur pasien yang sedikit berumur 51 tahun ke atas sebesar 7\% atau 10 responden. Gambar (b) menunjukkan jika proporsi pasien berjenis kelamin perempuan memiliki persentase 53\% lebih tinggi dibanding laki-laki yang memiliki persentase $47 \%$ dari total responden sebanyak 140 pasien/responden.

Jika dilihat dari pelayanan yang dirasakan pasien Gambar (j) menunjukkan jika sebesar $44 \%$ pasien merasakan durasi pelayanan kesehatan yang dialami kurang dari 15 menit, hal ini menurut Dinas Kesehatan Kabupaten Blitar merupakan waktu yang termasuk singkat, guna memberikan pelayanan kesehatan yang cepat, tanggap, dan maksimal untuk pasien. Gambar (k) menunjukkan bahwa sebesar $63 \%$ pasien yang datang ke puskesmas mendapatkan pelayanan kesehatan baik dari mulai poli hingga apotek tanpa membayar atau gratis. Disusul pengguna BPJS $18 \%$, dan pasien yang membayar secara umum sebesar $19 \%$.

Gambar 3 berisikan deskriptif variabel penelitian dari pelaksana puskesmas yang diduga Dinas Kesehatan Kabupaten Blitar mempunyai pengaruh terhadap kepuasan pelaksana terhadap Sistem Informasi Manajemen Puskesmas Elektronik (Simpustronik).

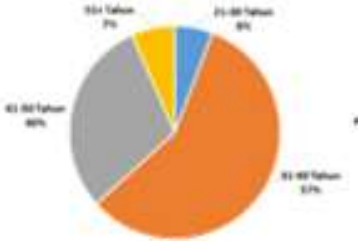

(a)

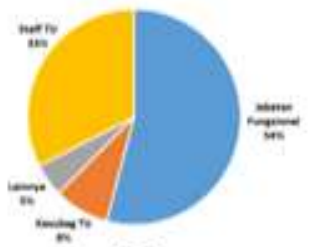

(c)

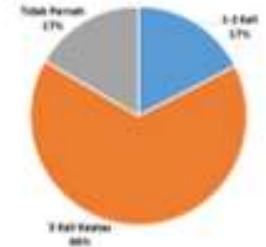

(e)

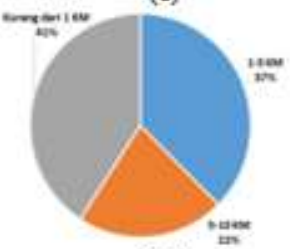

(g)

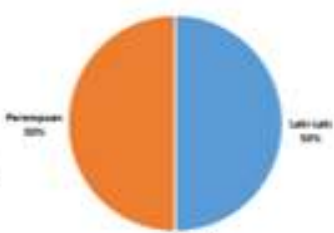

(b)

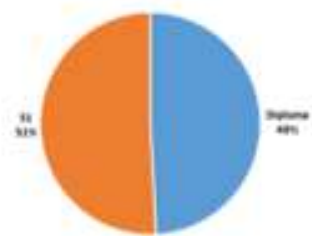

(d)

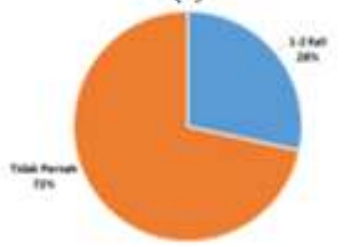

(f)

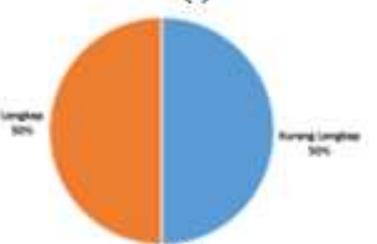

(h)

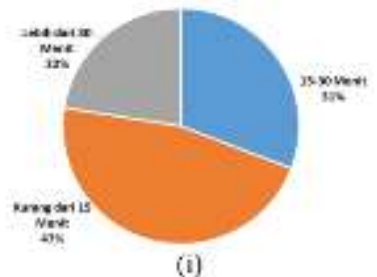

Gambar 3. Karakteristik Pelaksana

Berdasarkan karakteristik pelaksanan jika dilihat dari demografinya Gambar (a) menunjukkan bahwa rata-rata umur responden pada survei kepuasan pelaksana paling banyak pada umur 31-40 tahun yaitu sebesar 57\%. Kemudian rata-rata umur pelaksana yang sedikit berumur 21-30 tahun sebesar $6 \%$. Sedangkan proporsi jenis kelamin sampel pelaksana yang terambil terbagi rata dengan persentase $50 \%$ perempuan dan 50\% laki-laki sesuai pada Gambar (b). Gambar (d) menunjukkan pendidikan terakhir pelaksana puskesmas didominasi oleh S1 sebesar 51\% dan sisanya Diploma. 
Berdasarkan Gambar (f) menunjukkan ternyata pelaksana tidak pernah memperoleh sosialisasi Simpustronik persentase sebesar $72 \%$. Hal ini sedikit membuat kontra dengan kenyataan jika pelaksana merasa puas, ini dikarenakan disaat Dinas Kesehatan telah memberikan sosialisasi jika ada pembaharuan sistem bagi, justru tidak semua pelaksana tersebut datang, hanya diwakilkan lalu saling memberitahu pelaksana lainnya. Hal ini tentunya membuat persentase pelaksana yang menyatakan tidak pernah memperoleh sosialisasi Simpustronik begitu banyak.

\section{Gap Antara Kenyataan dan Harapan}

Hasil analisis gap menggunakan uji Wilcoxon untuk setiap dimensi, sesuai Tabel 2.

Tabel 2 Hasil Uji Wilcoxon untuk Setiap Dimensi

\begin{tabular}{|c|c|c|c|c|c|}
\hline \multirow{2}{*}{$\begin{array}{l}\text { Dimensi } \\
\text { (Pasien) }\end{array}$} & \multicolumn{2}{|c|}{ Statistik Uji } & \multirow{2}{*}{$\begin{array}{c}\text { Dimensi } \\
\text { (Pelaksana) }\end{array}$} & \multicolumn{2}{|c|}{ Statistik Uji } \\
\hline & $\mathbf{Z}$ & P-value & & $\mathbf{Z}$ & $\begin{array}{c}\mathrm{P}- \\
\text { value }\end{array}$ \\
\hline Res & $-9,1$ & 0,0 & $P$ & $-7,6$ & 0,0 \\
\hline Rel & $-10,3$ & 0,0 & $\mathrm{KP}$ & $-8,2$ & 0,0 \\
\hline Tan & $-8,3$ & 0,0 & $\mathrm{KS}$ & $-7,4$ & 0,0 \\
\hline Ass & $-9,5$ & 0,0 & KI & $-8,9$ & 0,0 \\
\hline \multirow[t]{2}{*}{ Emp } & $-8,5$ & 0,0 & KU & $-7,7$ & 0,0 \\
\hline & & & KL & $-8,8$ & 0,0 \\
\hline
\end{tabular}

Berdasarkan Tabel 2 dengan keterangan dimensi Res (Responsiveness), Rel (Reliability), Tan (Tangible), Ass (Assurance), Emp (Empathy) dan $\mathrm{P}$ (Pengguna), KP (Kepuasan Pengguna), KS (Kualitas Sistem), KI (Kualitas Informasi), KU (Keuntungan), KL (Kualitas Pelayanan) dapat diketahui nilai $p$-value yang adalah 0,0 , dengan menggunakan taraf signifikansi $5 \%$ dapat disimpulkan rata-rata kenyataan dan harapan pada kepuasan pasien dan pelaksana berbeda, atau terdapat kesenjangan antara harapan dan kenyataan yang diinginkan pasien dan pelaksana terhadap Simpustronik.

\section{Posisi Kuadran Dimensi Kepuasan}

Hasil analisis kuadran untuk menentukan performa penting yang dipertahankan atau diperbaiki pada Gambar 4.

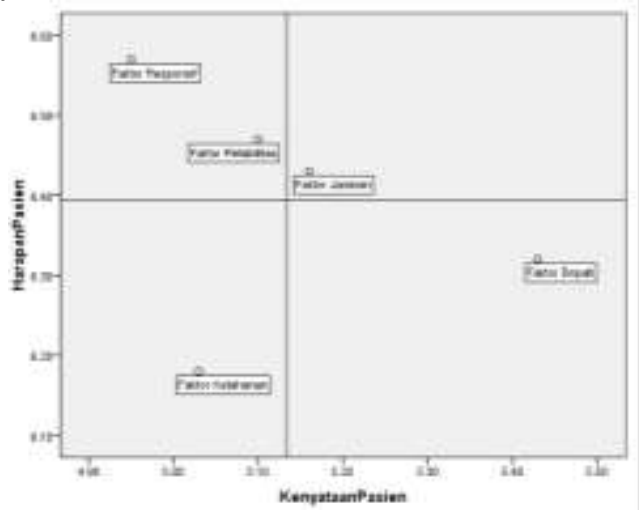

Gambar 4 Hasil Analisis Kuadran untuk Kepuasan Pasien

Gambar 4 menunjukkan bahwa seluruh faktor-faktor kepuasan pasien tersebar di kuadran I (Prioritas Utama) berisi faktor responsif dan faktor reliabilitas dimana kedua faktor ini perlu dilakukan perbaikan supaya kepuasan pasien terhadap Simpustronik tetap terjaga. Kuadran II (Pertahankan Prestasi) berisikan faktor jaminan perlu dipertahankan performanya karena pasien merasakan Simpustronik memberikan info yang terjamin. Kuadran III (Prioritas Rendah) berisikan faktor ketahanan perlu juga diperbaiki namun tidak sampai menjadi prioritas utama. Kuadran IV (Berlebihan) berisikan faktor empati yang berarti pasien sudah merasa puas terhadap Simpustronik dari segi empati.

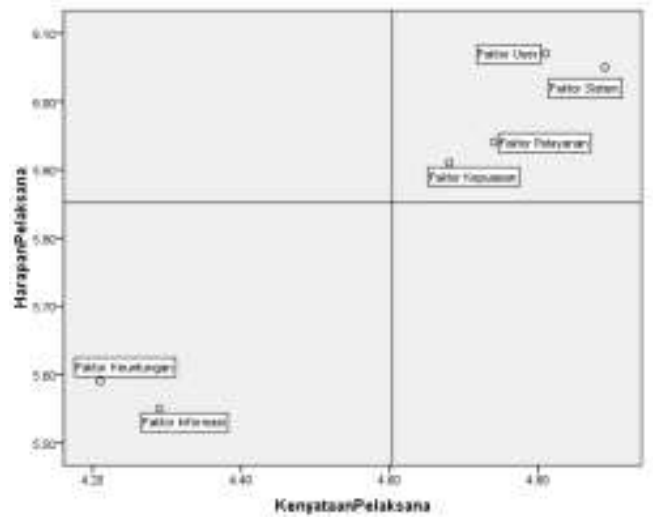

Gambar 5 Hasil Analisis Kuadran untuk Kepuasan Pelaksana Gambar 5 menunjukkan bahwa faktor-faktor kepuasan pelaksana tersebar di Kuadran II (Pertahankan Prestasi) yang berisikan faktor user, faktor sistem, faktor pelayanan, dan faktor kepuasan, keempat faktor tersebut perlu dipertahankan performanya karena kenyataan dan harapan yang dirasakan pelaksana tidak berbeda jauh dan diindikasikan pelaksana merasa terbantu dengan adanya Simpustronik. Serta Kuadran III (Prioritas Rendah) berisikan faktor keuntungan dan faktor informasi perlu juga diperbaiki meski bukan prioritas utama.

\section{Perhitungan Indeks Kepuasan Pengguna}

Hasil perolehan indeks kepuasan dari pasien dan pelaksana sesuai pada Tabel 3 .

$\underline{\text { Tabel } 3 \text { Hasil Indeks Kepuasan Pasien dan Pelaksana }}$

\begin{tabular}{ccccc}
\hline No. & Pengguna & Nilai & $\begin{array}{c}\text { Posisi } \\
\text { Indeks }\end{array}$ & Kriteria \\
\hline 1. & Pasien & $\begin{array}{c}0,733 \\
6\end{array}$ & 2 & Puas \\
2. & Pelaksana & $\begin{array}{c}0,659 \\
0\end{array}$ & 2 & Puas \\
\hline
\end{tabular}

Hasil Tabel 3 menunjukkan bahwa nilai indeks untuk kepuasan pasien sebesar 0,7336 dan nilai indeks kepuasan pelaksana sebesar 0,659 dan keduanya memiliki kriteria yang sama yaitu puas terhadap Simpustronik.

\section{Pemodelan Regresi Logistik Biner}

Hasil pemodelan dengan menggunakan Regresi Logistik untuk Kepuasan Pasien dan Pelaksana bertujuan untuk memprediksi karakteristik pasien dan pelaksana yang memiliki pengaruh signifikan terhadap kepuasan pada Simpustronik.

\section{a. Pengujian Serentak}

Hasil pengujian secara serentak untuk karakteristik pasien diperoleh pada Tabel 4.

Tabel 4 Hasil Uji Serentak Kepuasan Pasien

\begin{tabular}{ccccc}
\hline Keterangan & Chi-Square & DF & $\begin{array}{c}\text { P- } \\
\text { Value }\end{array}$ & $\chi_{0,2 ; 8}^{2}$ \\
\hline Pasien & 20,141 & 8 & 0,010 & 11,03 \\
Pelaksana & 10,077 & 6 & 0,121 & 8,56 \\
\hline
\end{tabular}

Hasil pengujian serentak dengan menggunakan taraf signifikan $20 \%$ pada Tabel 4 , diperoleh nilai chi-square untuk karakteristik pasien sebesar 20,141 lebih besar dari 11,03, dan nilai chi-square untuk karakteristik pelaksana sebesar 10,077 
lebih besar dari 8,56. Hal tersebut bermakna bahwa minimal ada satu karakteristik pasien dan pelaksana berpengaruh secara signifikan terhadap kepuasan pasien dan pelaksana pada Simpustronik

\section{b. Pengujian Parsial}

Hasil pengujian secara parsial untuk karakteristik pasien diperoleh pada Tabel 5.

Tabel 5 Hasil Uji Parsial Kepuasan Pasien

\begin{tabular}{|c|c|c|c|c|c|}
\hline & Variabel & $\bar{\beta}$ & Wald & DF & $P$-value \\
\hline \multirow[t]{3}{*}{$\mathbf{X}_{1}$} & JenisKelamin(1) & $\mathbf{0 , 8 3 0}$ & $\begin{array}{c}4,45 \\
1\end{array}$ & 1 & $\mathbf{0 , 0 3 5}$ \\
\hline & Pekerjaan(1) & 0,024 & $\begin{array}{c}0,00 \\
2\end{array}$ & 1 & 0,968 \\
\hline & Pekerjaan(2) & $-0,947$ & $\begin{array}{c}1,76 \\
7\end{array}$ & 1 & 0,184 \\
\hline \multirow{2}{*}{$\mathbf{X}_{2}$} & Pekerjaan(3) & 0,455 & $\begin{array}{c}\mathbf{0 , 5 5} \\
\mathbf{6}\end{array}$ & 1 & 0,456 \\
\hline & Pekerjaan(4) & $-0,370$ & $\begin{array}{c}0,23 \\
9\end{array}$ & 1 & 0,625 \\
\hline $\mathbf{X}_{7}$ & $\begin{array}{l}\text { Datang pada Bulan } \\
\text { April(1) }\end{array}$ & 0,999 & $\begin{array}{c}5,97 \\
4\end{array}$ & 1 & 0,015 \\
\hline $\mathbf{X}_{14}$ & $\operatorname{Jarak}(1)$ & 0,899 & $\begin{array}{c}5,35 \\
8\end{array}$ & 1 & 0,021 \\
\hline \multirow[t]{2}{*}{$X_{16}$} & DurasiPelayanan(1) & $-0,591$ & $\begin{array}{c}2,48 \\
5\end{array}$ & 1 & $\mathbf{0 , 1 1 5}$ \\
\hline & Constant & $-0,993$ & $\begin{array}{c}2,46 \\
9\end{array}$ & 1 & 0,116 \\
\hline
\end{tabular}

Tabel 6 Hasil Uji Parsial Kepuasan Pelaksana

\begin{tabular}{|c|c|c|c|c|c|}
\hline & Variabel & $\beta$ & Wald & DF & P-value \\
\hline $\mathbf{X}_{3}$ & Usia Pelaksana & $\mathbf{0 , 0 3 4}$ & $\begin{array}{c}0,79 \\
9\end{array}$ & 1 & $\mathbf{0 , 3 7 1}$ \\
\hline $\mathrm{X}_{4}$ & Pendidikan(1) & $-0,657$ & $\begin{array}{c}1,93 \\
6\end{array}$ & 1 & 0,164 \\
\hline $\mathrm{X}_{9}$ & Masa Kerja & $\mathbf{0 , 0 3 4}$ & $\begin{array}{c}1,31 \\
9\end{array}$ & 1 & 0,251 \\
\hline $\mathbf{X}_{11}$ & Guna Simpus(1) & 0,438 & $\begin{array}{c}\mathbf{0 , 8 2} \\
\mathbf{3}\end{array}$ & 1 & 0,364 \\
\hline $\mathbf{X}_{13}$ & Sosil Simpus(1) & $-0,419$ & $\begin{array}{c}0,68 \\
3\end{array}$ & 1 & $\mathbf{0 , 4 0 8}$ \\
\hline $\mathrm{X}_{14}$ & $\operatorname{Jarak}(\mathbf{1})$ & $\mathbf{0 , 2 8 8}$ & $\begin{array}{c}\mathbf{0 , 5 4} \\
0\end{array}$ & 1 & 0,463 \\
\hline & Constant & $-1,57$ & 1,18 & 1 & 0,277 \\
\hline
\end{tabular}

Hasil pengujian parsial untuk karakteristik pasien Tabel 5 diperoleh 5 variabel yang memiliki nilai Wald yang lebih dari $Z_{0,2 / 2}$ sebesar 0,54 , sehingga dapat disimpulkan jika karakteristik pasien terdiri dari jenis kelamin, pekerjaan, instensitas datang ke puskesmas bulan April, jarak tempat tinggal, dan durasi pelayanan, berpengaruh signifikan terhadap kepuasan pasien pada Simpustronik. Pada Tabel 5 diketahui nilai Odds Ratio tertinggi pada karakteristik intensitas pasien ke puskesmas pada bulan April kurang dari 2 kali cenderung merasa puas terhadap Simpustronik 2,714 lebih tinggi dibanding yang lebih dari 2 kali. Model tersebut memiliki nilai Nagelkerke $R^{2}$ sebesar 0,179 . Artinya variabel prediktor yang masuk ke dalam model dapat menjelaskan keragaman respon sebesar $17,9 \%$. Model logitnya sebagai berikut.

$$
\pi(x)=\frac{e^{\hat{g}(x)}}{1+e^{\hat{g}(x)}}
$$

dengan

$$
\begin{aligned}
\hat{g}(x)= & -0,993+0,83 X 1_{(1)}-0,947 X 2_{(2)}+0,455 X 2_{(3)} \\
& +0,999 X 7_{(1)}+0,899 X 14_{(1)}-0,591 X 16_{(1)}
\end{aligned}
$$

Berdasarkan model logit untuk variabel tersebut jika diisi sesuai dengan kategori dalam model tersebut, maka didapatkan probabilitas pasien akan merasa puas terhadap Simpustronik sebesar $65,7 \%$. Hasil uji parsial untuk pelaksana pada Tabel 6 .

Hasil pengujian parsial untuk karakteristik pelaksana Tabel 6 diperoleh 6 variabel yang memiliki nilai Wald yang lebih dari $Z_{0,2 / 2}$ sebesar 0,54 sehingga dapat disimpulkan jika variabel karakteristik usia, pendidikan, masa kerja, intensitas menggunakan Simpus, intensitas memperoleh sosialisasi Simpus, dan jarak tempat tinggal, berpengaruh signifikan terhadap kepuasan pelaksana pada Simpustronik. Berdasarkan Tabel 6 diketahui nilai Odds Ratio tertinggi pada karakteristik pelaksana yang menggunakan Simpus kurang dari 5 kali cenderung merasa puas terhadap Simpustronik 1,549 lebih tinggi dibanding yang 5 kali keatas. Model tersebut memiliki nilai Nagelkerke $R^{2}$ sebesar 0,107 . Artinya variabel prediktor yang masuk ke dalam model dapat menjelaskan keragaman respon sebesar 10,7\%. Model logitnya sebagai berikut.

$$
\pi *(x)=\frac{e^{\hat{g}^{*}(x)}}{1+e^{\hat{\beta}^{*}(x)}}
$$

dengan

$$
\begin{aligned}
\hat{g} *(x) & =2,813+0,034 X 3-0,657 X 4_{(1)}+0,034 X 9 \\
& +0,438 X 11_{(1)}-0,419 X 13_{(1)}+0,288 X 14_{(1)}
\end{aligned}
$$

Berdasarkan model logit untuk variabel tersebut jika diisi sesuai dengan kategori dalam model tersebut, maka didapatkan probabilitas pasien akan merasa puas terhadap Simpustronik sebesar $13,6 \%$.

c. Uji Kesesuaian Model

Berdasarkan hasil uji kesesuaian model diperoleh nilai chi square untuk pasien sebesar 5,176 dan pelaksana sebesar 9,681 . Keduanya kurang dari $\chi_{0,2 ; 8}^{2}$ sebesar 11,03 , sehingga dapat disimpulkan telah sesuai atau tidak terdapat perbedaan yang signifikan antara hasil pengamatan dengan kemungkinan hasil prediksi model.

\begin{tabular}{|c|c|c|c|c|}
\hline \multirow{3}{*}{\multicolumn{2}{|c|}{ Observasi }} & \multicolumn{3}{|c|}{ Prediksi } \\
\hline & & \multicolumn{2}{|c|}{ Kepuasan Pasien } & \multirow{2}{*}{ Persentase } \\
\hline & & Tidak Puas & Puas & \\
\hline Kepuasan & Tidak Puas & 43 & 23 & 65,2 \\
\hline Pasien & Puas & 23 & 51 & 68,9 \\
\hline \multicolumn{2}{|c|}{ Persentase keseluruhan } & & & 67,1 \\
\hline
\end{tabular}

d. Ketepatan Klasifikasi

Ketepatan klasifikasi model berguna untuk mengetahui seberapa besar data diklasifikasikan dengan benar atau tidak hasilnya pada Tabel 7 dan Tabel 8.

Tabel 7 Ketepatan Klasifikasi Kepuasan Pasien 
Tabel 8 Ketepatan Klasifikasi Kepuasan Pelaksana

\begin{tabular}{|c|c|c|c|c|}
\hline \multirow{3}{*}{\multicolumn{2}{|c|}{ Observasi }} & \multicolumn{3}{|c|}{ Prediksi } \\
\hline & & \multicolumn{2}{|c|}{ Kepuasan Pelaksana } & \multirow{2}{*}{ Persentase } \\
\hline & & Tidak Puas & Puas & \\
\hline Kepuasan & Tidak Puas & 37 & 23 & 61,7 \\
\hline Pelaksana & Puas & 23 & 37 & 61,7 \\
\hline \multicolumn{2}{|c|}{ Persentase keseluruhan } & & & 61,7 \\
\hline
\end{tabular}

Hasil ketekapan klasifikasi untuk kepuasan pasien Tabel 7 dan kepuasan pelaksana Tabel 8 diperoleh sebesar $67,1 \%$ untuk kepuasan pasien dan $61,7 \%$ untuk kepuasan pelaksana pelaksana. Ketepatan klasifikasi dari kedua model tersebut dapat dikatakan bagus karena mampu memberikan hasil lebih dari $50 \%$ atau setengah lebih dari jumlah sampel yang ada.

Berdasarkan variabel penelitian terdapat karakteristik yang sama antara pasien dan pelaksana, sehingga pada Tabel 9 jika nilai Wald lebih dari $Z_{0,2 / 2}$ sebesar 0,54 maka karakteristik berpengaruh signifikan terhadap kepuasan. Hasil uji Wald diperoleh dari model awal sebelum diperoleh model akhir seperti pada Tabel 5 dan Tabel 6, tujuannya untuk mengetahui diantara karakteristik yang berpengaruh signifkan dan diharapkan dapat digunakan untuk penelitian selanjutnya.

Tabel 9 Hasil Signifikansi Parameter untuk Karakteristik yang Sama

\begin{tabular}{lcc}
\hline \multirow{2}{*}{ Variabel } & Pasien & Pelaksana \\
\cline { 2 - 3 } & Wald & Wald \\
\hline Jenis Kelamin & $\mathbf{4 , 3 4 7}$ & 0,014 \\
Usia & 0,153 & $\mathbf{0 , 9 0 1}$ \\
Pendidikan & 0,019 & $\mathbf{2 , 1 2 3}$ \\
Jarak & $\mathbf{5 , 0 4 6}$ & $\mathbf{0 , 7 0 2}$ \\
Info Lengkap & 0,165 & 0,208 \\
Durasi Pelayanan & $\mathbf{2 , 2 4 9}$ & 0,037 \\
\hline
\end{tabular}

Berdasarkan Tabel 9 diketahui jika dari 6 variabel karakteristik yang sama diperoleh karakteristik jenis kelamin dan durasi pelayanan memiliki pengaruh yang signifikan terhadap kepuasan pasien. Usia dan pendidikan memiliki pengaruh yang signifikan terhadap kepuasan pelaksana pada Simpustronik. Jarak rumah dengan puskesmas memiliki pengaruh yang signifikan terhadap kepuasan pasien dan pelaksana, sedangkan karakteristik info lengkap tidak memiliki pengaruh yang signifikan terhadap kepuasan pasien dan pelaksana.

\section{KESIMPULAN DAN SARAN}

\section{Kesimpulan}

Kesimpulan yang didapatkan menunjukkan hasil uji validitas dan reliabilitas dengan menggunakan second order confirmatory factor analysis (CFA), untuk kepuasan pasien diperoleh 15 indikator valid dengan 5 dimensi yang dapat dihandalkan, sedangkan untuk kepuasan pelaksana diperoleh 13 indikator valid dengan 6 dimensi yang mampu dihandalkan. A.Terdapat gap (kesenjangan) antara kenyataan dan harapan yang dirasakan oleh pasien dan pelaksana terhadap Simpustronik.

B.Posisi kuadran dimensi pengukur kepuasan pasien dan pelaksana, diperoleh hasil sebagai berikut.

a. Penyusun Kepuasan Pasien Terhadap Simpustronik

Faktor responsif dan faktor reliabilitas merupakan prioritas utama untuk dilakukan perbaikan oleh pengelola sistem. Faktor Jaminan, menunjukkan jika pasien sudah merasa terjamin dengan pelayanan kesehatan yang ada, sehingga perlu dipertahankan.

b. Penyusun Kepuasan Pelaksana Terhadap Simpustronik Faktor user, faktor kepuasan, faktor sistem, dan faktor pelayanan patut dipertahankan oleh pengelola sistem.

C. Indeks kepuasan pasien diperoleh nilai sebesar 0,7336 dan indeks kepuasan pelaksana nilai sebesar 0,659 dan memiliki keterangan yang sama yaitu puas terhadap Simpustronik.

D.Pemodelan Regresi Logistik Biner.

a. Regresi Logistik Biner Untuk Kepuasan Pasien Terhadap Simpustronik, diperoleh model logit sebagai berikut.

$$
\begin{aligned}
\hat{g}(x)= & -0,993+0,83 X 1_{(1)}-0,947 X 2_{(2)}+0,455 X 2_{(3)} \\
& +0,999 X 7_{(1)}+0,899 X 14_{(1)}-0,591 X 16_{(1)}
\end{aligned}
$$

Dengan probabilitas pasien akan merasa puas terhadap Simpustronik sebesar $65,7 \%$. Ketepatan klasifikasi sebesar $67,1 \%$.

b. Regresi Logistik Biner Untuk Kepuasan Pelaksana Terhadap Simpustronik, diperoleh model logit.

$$
\begin{aligned}
\hat{g} *(x) & =2,813+0,034 X 3-0,657 X 4_{(1)}+0,034 X 9 \\
& +0,438 X 11_{(1)}-0,419 X 13_{(1)}+0,288 X 14_{(1)}
\end{aligned}
$$

Dengan probabilitas pelaksana akan merasa puas terhadap Simpustronik sebesar 13,6\%. Ketepatan klasifikasi sebesar $61,7 \%$.

c. Berdasarkan 6 variabel karakteristik yang sama diperoleh karakteristik jenis kelamin dan durasi pelayanan berpengaruh signifikan terhadap kepuasan pasien. Usia dan pendidikan berpengaruh signifikan terhadap kepuasan pelaksana pada Simpustronik. Jarak rumah dengan puskesmas berpengaruh signifikan terhadap kepuasan pasien dan pelaksana, sedangkan karakteristik info lengkap tidak berpengaruh signifikan terhadap kepuasan pasien dan pelaksana.

2. Saran

Dari hasil penelitian, terdapat beberapa saran yaitu sebagai berikut.

1. Pengelola sistem dapat segera melakukan evaluasi dan perbaikan sesuai prioritas utama yang telah diperoleh, dan berdasarkan kecenderungan (Odds Ratio) ketidakpuasan.

2. Koordinasi guna penelitian lanjutan dengan pihak Dinas Kesahatan untuk menentukan variabel karakteristik lain yang berpengaruh pada kepuasan pasien dan pelaksana sehingga mampu memberikan model yang lebih baik, serta penambahan indikator untuk meminimalisir kemungkinan terjadinya fenomena Heywood Case atau kesalahan pemodelan.

\section{DAFTAR PUSTAKA}

[1] S. Santoso, Statistik Nonparametrik, Jakarta: PT. Elex Media Komputindo, 2010.

[2] F. Tjiptono and G. Chandra, Service, Quality, and Satisfaction (3 ed.), Yogyakarta, 2011.

[3] Aritonang and R. Lerbin, Kepuasan Pelanggan Pengukuran dan Penganalisisan dengan SPSS, Jakarta: PT. Gramedia Pustaka Utama, 2005.

[4] Hosmer and Lemeshow, Applied Logistic Regression, USA: John Wiley \& Sons, 2000. 
[5] Parasuraman, V. A. Zeithaml and L. L. Berry, "SERVQUAL:A multiple-Item Scale for Measuring Consumer Perceptions of Service Quality.," Journal of Retailing, vol. 64, no. 1, 1998.

[6] DeLone and McLean, "The DeLone and McLean Model of Information Systems Success: A Ten-Year Update," Journal of Management Information Systems, vol. 19, no. 14, pp. 9-30, 2003.

[7] R. Walpole, Intoduction to Statistics, New York: Macmillan Publishing Co. Inc, 1995.

[8] I. Ghozali, Structural Equation Modeling Metode Alternatif dengan Partial Least Square (PLS), Semarang: Universitas Diponegoro, 2011.

[9] J. Hair, W. C. Black, W. J. Babin and R. Anderson, Multivariate Data Analysis., New Jersey: Pearson Education International, 2010.

[10] W. Mendenhall, Statistika untuk Manajemen dan Ekonomi, Jakarta: Penerbit Erlangga, 1982. 